JOLANTA WASILEWSKA* - LUBLIN

\title{
O POTRZEBIE OCHRONY ZBIORÓW BIBLIOTECZNYCH
}

Słowo utrwalone na piśmie - myśl ludzka - było i jest jednym z podstawowych środków przekazu za pomocą którego cywilizacje mogły się rozwijać, przekazując następcom (świadomie lub nieświadomie) dziedzictwo własnych dokonań. Niestety przekaz pisemny dociera do potomnych często w małych fragmentach, a niekiedy wręcz $\mathrm{w}$ formie szczątkowej i to nie tylko z powodu świadomych niszczycielskich działań człowieka czy nieprzewidywalnych działań żywiołów ognia i wody, ale również nietrwałości materiału na którym zapisano przekaz słowny.

Dla współczesnej cywilizacji powinnością i troską jest staranie, aby zachować jak najdłużej dorobek intelektualny człowieka. Dlatego tez zadaniem archiwistów i bibliotekarzy jest jak najdokładniejsze wypełnianie spoczywającej na nich „misji”.

Materiały na których zapisano teksty w większości są pochodzenia organicznego, dlatego też zbiory nieuchronnie starzeją się i niszczeją. Nasze zadanie polega na tym, aby te procesy - dzięki umiejętnym działaniom - w dużej mierze opóźnić. Działania te wbrew pozorom są bardzo trudne i mogą być skuteczne jedynie przy wykorzystaniu pogłębionej współczesnej wiedzy i zastosowaniu nowoczesnych specjalistycznych środków chemicznych i technicznych.

$\mathrm{W}$ różnych bibliotekach czynności zmierzające $\mathrm{w}$ kierunku ochrony zbiorów są różne i są zależne od wielu warunków, takich jak: usytuowanie budynku (miasto przemysłowe, bliskość drzew i wody - staw, jezioro, rzeka), architektura (gmach budowany z przeznaczeniem dla biblioteki lub przystosowany), a przede wszystkim uzależnione są od wieku gromadzonych książek. Inne warunki muszą być zapewnione w pomieszczeniach, gdzie gromadzone są manuskrypty i starodruki, inne zaś w tych, gdzie umieszczone są wydawnictwa z XIX i XX wieku

* Jolanta Wasilewska - kierownik Pracowni Konserwacji Zbiorów Zabytkowych i Introligatorni Biblioteki Uniwersyteckiej KUL.

${ }^{1}$ Olbrzymie znaczenie ma wybór odpowiednich pomieszczeń na magazynowanie książek. Zbiorów nie należy umieszczać w piwnicach ani na poddaszach. Trzeba pamiętać aby w pomieszczeniach była odpowiednia temperatura i wilgotność powietrza. Specjalistyczne badania wykazały, że najkorzystniejsza temperatura dla magazynierów i zbiorów archiwalnych jest $\mathrm{w}$ granicach od $16^{\circ}$ do $18^{\circ} \mathrm{C}$, a dla mikrofilmów i nośników elektronicznych od $10^{\circ}$ do $16^{\circ} \mathrm{C}$. Równie ważna jest wil- 
Nowoczesna polityka ochrony zbiorów w bibliotece powinna być kreatywna. Współczesny bibliotekarz (pracownik służby bibliotecznej) nie może już ograniczyć się tylko do udostępniania czy wypożyczenia książki czytelnikowi, ale musi czuć się odpowiedzialny za stan zachowania zbiorów oraz posiąść zdolność zarządzania powierzonymi mu zasobami w szerokim tego słowa znaczeniu. Nowoczesny bibliotekarz (także magazynier) powinien nie tylko znać wartość zbiorów, ale też dbać o zachowywanie właściwych warunków przechowywania. Do wypełnienia tych zadań winien stale się dokształcać i pogłębiać szybko rozwijającą się wiedzę z dziedziny bibliotekarstwa, a szczególnie dotyczącą zagrożeń jakie mogą powodować czynniki atmosferyczne i biologiczne. Na przykład powinien wiedzieć czy i kiedy można otwierać okna w magazynie czy czytelni (deszcz, upał, mróz, smog), powinien unikać przechowywania i spożywania posiłków w magazynie (resztki jedzenia), musi wiedzieć kiedy oddzielić zainfekowaną książkę (pleśń) od zdrowych, a także musi szybko reagować na fizyczne uszkodzenia książek przez użytkowników, powinien też być nieustannie czujny i zwracać uwagę na wszystko co mogłoby spowodować niebezpieczeństwo dla zbiorów (instalacja elektryczna, grzewcza czy kanalizacja).

W bibliotekach na całym świecie udostępniane materiały biblioteczne, oprócz narażenia na kradzież, ulegają mechanicznym zniszczeniom - takim jak: zagięcia rogów kart, przedarcia, wycinanie ilustracji, rysowanie, pisanie i podkreślanie na stronicach książek, plamienie produktami spożywczymi i chemicznymi, niefachowe kopiowanie i naprawianie książek, wydzieranie stron czy całych składek, oraz wielu innym najróżniejszym uszkodzeniom powodowanym przez beztroskiego czytelnika bądź nieuważnego bibliotekarza. Można śmiało powiedzieć, że pracownik biblioteki jest głównym ,stróżem” materiałów bibliotecznych! Magazynier i bibliotekarz powinien zwracać uwagę na stan zachowania książki przed udostępnieniem jej czytelnikowi i po jej zwrocie. Pracownicy muszą zwracać uwagę, aby osoby nieupoważnione nie miały dostępu do zbiorów najcenniejszych i z dużą ostrożnością udostępniać zbiory szczególnie chronione.

Zatem ochrona zbiorów jest zespołem różnych i złożonych działań, zmierzających do zapewnienia zbiorom bezpieczeństwa i dobrego stanu zachowania. Jest to jedno z podstawowych zadań biblioteki, ściśle związane z najważniejszymi jej funkcjami, takimi jak gromadzenie i udostępnianie zbiorów. Albowiem pełna ochrona zwiększa żywotność zbiorów i wydłuża czas ich użytkowania oraz umożliwia zachowanie ich dla przyszłych pokoleń.

Ważne jest aby pracownicy odpowiedzialni za bezpieczeństwo zbiorów ustalili priorytety i procedury na wypadek katastrof czy kataklizmów. Istotne jest opracowanie instrukcji postępowania w razie zagrożenia, jak również przeprowadzanie regularnych ćwiczeń. Za działania prewencyjne powinni być odpowiedzialni wszyscy pracownicy na poszczególnych szczeblach hierarchii organizacyjnej.

W wielu specjalistycznych czasopismach (,Notes Konserwatorski”, „Przegląd

gotność względna powietrza, która powinna zawierać się w granicach od 50 do $60 \%$. Wilgotność jest głównym i podstawowym czynnikiem sprzyjającym niszczeniu książek. Sprzyja ona rozwojowi owadów oraz umożliwia i pobudza do rozwoju grzyby mikroskopowe, popularnie zwane pleśniami. Suche powietrze natomiast powoduje kruszenie papieru, pęknięcia skóry i deformowanie opraw. 
Biblioteczny”, „Bibliotekarz”, „Roczniki Biblioteczne”), pojawiają się artykuły o konieczności kształcenia bibliotekarzy w dziedzinie ochrony zbiorów bibliotecznych. Pierwsze raporty poruszające ten problem pojawiły się już na początku lat osiemdziesiątych, opublikowane przez IFLA ${ }^{2}$

Szybki rozwój technologii przynosi coraz to nowe możliwości i równocześnie większe oczekiwania i wymagania użytkowników. Nowoczesne technologie (zwłaszcza elektroniczne) pozwalają chronić oryginały przed bezpośrednim kontaktem z czytelnikiem. Dysponujemy coraz większym wyborem urządzeń do tworzenia kopii. Skanery i kopiarki stosujące lampę z tzw. ,zimną katodą” i fotograficzne aparaty cyfrowe otwierają olbrzymie możliwości; pozwalają na szybkie wykonanie formy zastępczej dokumentu, przesłanie go na odległość i korzystanie jednocześnie kilku osobom jednocześnie. I choć nie wiemy jak długotrwałe będzie przechowywanie zdigitalizowanych obiektów na nowych nośnikach (dyskietki, płyty $\mathrm{CD}$, karty pamięci), to na pewno ta metoda znacznie wspomaga wysiłki zmierzające do jak najlepszej ochrony oryginałów. Narastająca świadomość bezpowrotnej utraty setek tysięcy dokumentów utrwalonych na papierze doprowadziła pod koniec XX wieku do poszukiwań sposobów na bardziej efektywne ratowanie niż tradycyjna, pojedyncza konserwacja obiektu. Poszukiwania poszły w dwóch kierunkach: z jednej rozwój metod konserwacji masowej, z drugiej wykorzystanie ciągle rozwijającej się technologii urządzeń do kopiowania. Ta idea była podstawą zainicjowanego przez UNESCO międzynarodowego programu Memory of the World (Pamięć Świata)

Polityka ochrony zbiorów we współczesnej bibliotece powinna być poparta wiedzą. $\mathrm{Na}$ te tematy dostępna jest bogata literatura oraz wiele fachowych czasopism, a także co roku organizowanych jest wiele sympozjów i konferencji poświęconych kierunkom rozwoju nowoczesnych metod ochrony zbiorów. Nie mniej ważna od fachowych zabiegów konserwatorskich jest profilaktyka. Właściwe przechowywanie, świadomość i wiedza personelu biblioteki mogą zapewnić bezpieczeństwo materiałom bibliotecznym ${ }^{4}$.

${ }^{2}$ IFLA (The International Federation of Library Associations and Institutions - Międzynarodowa Federacja Stowarzyszeń i Instytucji Bibliotecznych) jest wiodącym, międzynarodowym ciałem reprezentującym interesy bibliotekarzy, pracowników informacji i użytkowników w skali globalnej, jest niezależną, międzynarodową, pozarządową organizacją typu ,not-for-profit”. Jej główne cele to: promowanie wysokiego standardu usług bibliotecznych i informacyjnych; upowszechnianie rozumienia wartości dobrej biblioteki i serwisu informacyjnego; reprezentowanie interesów członków na całym świecie.

${ }^{3}$ W 1992 roku ówczesny dyrektor UNESCO zgłosił pomysł ochrony najbardziej narażonych na zniszczenie zbiorów stanowiących pomniki światowej kultury oraz ułatwienia dostępu do nich poprzez sporządzenie ich kopii na nośnikach cyfrowych.

${ }^{4}$ Olbrzymie znaczenie ma wybór odpowiednich pomieszczeń na magazynowanie książek. Zbiorów nie należy umieszczać w piwnicach ani na poddaszach. Trzeba pamiętać aby w pomieszczeniach była odpowiednia temperatura i wilgotność powietrza. Specjalistyczne badania wykazały, że najkorzystniejsza temperatura dla magazynierów i zbiorów archiwalnych jest $\mathrm{w}$ granicach od $16^{0}$ do $18^{\circ} \mathrm{C}$, a dla mikrofilmów i nośników elektronicznych od $10^{\circ}$ do $16^{\circ} \mathrm{C}$. Równie ważna jest wilgotność względna powietrza, która powinna kształtować się w granicach od 50 do $60 \%$. Wilgotność jest głównym czynnikiem sprzyjającym niszczeniu książek. Sprzyja ona rozwojowi owadów oraz 
Dobrze zorganizowane i systematycznie przeprowadzanie zabiegi profilaktyczne najlepiej chronią zbiory przed zniszczeniem i co za tym idzie, zmniejszają wydatki na bardzo kosztowne i czasochłonne zabiegi konserwatorskie ${ }^{5}$.

Odpowiedzialność za ochronę zbiorów bibliotecznych regulują przede wszystkim odpowiednie przepisy prawne, zawarte w ustawach i rozporządzeniach o bibliotekach ${ }^{6}$.

W Polsce na problemem ratowania dziedzictwa narodowego z XIX i XX wieku wspaniale zareagowała Rada Ministrów Rzeczpospolitej Polskiej uchwałą z 17 listopada 1999 roku i przyjęła wieloletni program rządowy na lata 2000-2008 „Kwaśny papier. Ratowanie w skali masowej zagrożonych polskich zasobów bibliotecznych i archiwalnych"7.

Coraz więcej organizacji rządowych i pozarządowych, przede wszystkim w krajach rozwiniętych, włącza się w parce w zakresie ratowania zbiorów. Pierwszeństwo w tym zakresie wiodą Stany Zjednoczone, Anglia, Kanada, Niemcy i Francja. Świadomość zagrożeń i stale rosnących potrzeb jest tam o wiele bardziej powszechna niż gdzie indziej. Stosuje się tam już od wielu lat metody masowej konserwacji, mikrofilmuje i digitalizuje zbiory, ale i prowadzi prace badawcze. Prowadzenie badań, poszukiwanie nowych rozwiązań wymaga współpracy bibliotekarzy i konserwatorów, pracowników naukowych i technicznych wielu specjalności: biologów, chemików, fizyków, papierników, a także wydawców i drukarzy, organizacji i instytucji wielu krajów - tylko w ten sposób możemy uratować nasze kulturowe dziedzictwo. Tylko współpraca organizacji i instytucji o zasięgu światowym może doprowadzić do stworzenia efektywnych programów ratowania naszego dziedzictwa kulturowego, którymi są zbiory biblioteczne.

Czy można ochronić wszystkie zbiory w naszych bibliotekach?

Jest to pytanie czysto retoryczne. Niestety, jest to niemożliwe - nawet w najbogatszych krajach i w najlepiej uposażonych bibliotekach. Może w przyszłości powstaną nowe, bardziej skuteczne i wydajne metody, lecz teraz, aby ratować jak najwięcej cennych oryginałów, polityka ochrony zbiorów musi mieć charakter

umożliwia i pobudza do rozwoju grzyby mikroskopowe, popularnie zwane pleśniami. Natomiast zbyt niska wilgotność powietrza, a zwłaszcza podwyższona temperatura, powodują kruszenie papieru, pęknięcia skóry i deformowanie opraw. Innym ważnym czynnikiem, który zagraża zbiorom jest światło. Każdy rodzaj światła jest szkodliwy, a każde jego ograniczenie korzystne.

${ }^{5}$ Dobrą okazją na przegląd stanu zachowania zbiorów może być regularnie przeprowadzanie skontrum.

${ }^{6}$ Ustawa z dnia 27 czerwca 1997 r. o bibliotekach (Dz.U. 1997 Nr 85, poz. 539 z późn. zm.)

${ }^{7}$ Program masowego ratowania zbiorów archiwalnych i bibliotecznych zakłada realizację następujących celów:

- Pełne i kompletne określenie zakresu zagrożeń, z wyselekcjonowaniem zbiorów bibliotecznych i archiwalnych według stopnia zagrożenia - w układzie geograficznym i administracyjnym kraju;

- Podjęcie stosownych działań prewencyjnych, ograniczających, a nawet, w niektórych wypadkach, wykluczających dopływ materiałów zakwaszonych do zbiorów;

- Stworzenie sieci instalacji masowego odkwaszania i wzmacniania dziewiętnastowiecznego i dwudziestowiecznego papieru nietrwałego, współdziałającej z urządzeniami do masowego mikrofilmowania zbiorów zagrożonych. 
selektywny i opierać się na wcześniej ustalonych priorytetach. Wybór powinien opierać się na przeprowadzonej selekcji zbiorów według określonych kryteriów formalnych i treściowych. Pod uwagę należy także brać unikatowość obiektów.

Aby chronić zbiory konieczna jest nie tylko świadomość pracowników biblioteki, ale pozytywne nastawienie odpowiednich instytucji naukowo-badawczych i rządowych oraz przekonanie, że ochrona zbiorów ma istotne znaczenie dla rozwoju nauki, techniki i kultury, i że bez koniecznych nakładów na ten cel wiele zbiorów bezpowrotnie zginie.

\section{Bibliografia}

M. Chmielnicka-Szymczak, E. Czerwińska, Ochrona zbiorów bib-liotecznych w Bibliotece Głównej Politechniki Opolskiej, http://212.33.67.2/mirror_libra/ chmielnicka-szymczak_czerwinska.pdf 2.

EbiB - http://ebib.oss.wroc.pl/2003/48/ifla.php

A. Manikowski, Przedmowa, „Notes Konserwatorski”, Warszawa 1998 r.

E. Stachowska-Musiał, Polityka ochrony zbiorów we współczesnym świecie, „Notes Konserwatorski", Warszawa 1999 r.

E. Stachowska-Musiał, Program UNESCO Pamięć Świata i wktad Polski w jego realizacje, „Notes Konserwatorski”, Warszawa 2002 r.

J. Wieprzkowski, Ochrona ksiązki dawniej i dziś, „Biblioteka w szkole”, Warszawa $1991 \mathrm{r}$.

M. Woźniak, D. Rams, Aktualne tendencje ochrony i konserwacji zbiorów bibliotecznych, „Notes Konserwatorski”, Warszawa 2003 r.

B. Zyska, Działania profilaktyczne w bibliotece, „Ochrona zbiorów bibliotecznych przed zniszczeniem", 3 (1994).

http://isip.sejm.gov.pl/prawo/index.html 


\section{ÜBER DIE NOTWENDIGKEIT DES SCHUTZES DER BIBLIOTHEKSBESTÄNDE}

\section{Zusammenfassung}

Für die heutige Zivilisation ist es Pflicht und Sorge, sich um die möglichst lange Erhaltung der intellektuellen Errungenschaften des Menschen zu kümmern. Unmittelbar wird diese Aufgabe von den Archivaren und Bibliothekaren realisiert. Zum Schutz von Büchersammlungen gehört ein ganzes Ensemble verschiedener und komplizierter Aktivitäten, die deren Sicherheit und einen guten Erhaltungszustand gewährleisten sollen. Die schnelle technologische Entwicklung bringt ständig neue Möglichkeiten und gleichzig auch größere Erwartungen und Anforderungen von Seiten der Benutzer mit sich. Das sich insbesondere gegen Ende des 20. Jahrhunderts vertiefende Bewusstsein des möglichen Verlustes Hunderttausender auf Papier gebannter Dokumente führte zu einer beschleunigten Suche nach besseren und effektiveren Methoden ihrer Rettung. Diese Suche verlief in zweierlei Richtungen: einerseits zur Entwicklung von Methoden massenhafter Konservierung und andererseits zur Nutzung der sich ständig weiterentwickelnden Technologie der Kopiergeräte. Dieser Gedanke bildete die Grundlage des von der UNESCO initiierten internationalen Programms „Memory of the World”. In Polen hat der Ministerrat der Republik Polen auf das Problem der Rettung des Nationalerbes aus dem 19. und 20. Jahrhundert mit dem Beschluss vom 17. November 1999 hervorragend reagiert und ein Langfristiges Regierungsprogramm für die Jahre 2000-2008 „Saures Papier. Zur massenhaften Rettung der bedrohten polnischen Bibliotheks- und Archivbestände" verabschiedet. Um diese Bestände zu schützen, ist nicht nur ein entsprechendes Bewusstsein der Bibliotheksmitarbeiter notwendig, sondern auch die positive Einstellung der entsprechenden wissenschaftlichen Forschungseinrichtungen und Regierungsstellen sowie die Überzeugung, dass der Schutz dieser Bestände von ganz wesentlicher Bedeutung für die Entwicklung der Wissenschaft, der Technik und der Kultur ist und dass ohne die notwendigen Zuwendungen zu diesem Zweck viele Bestände unwiederbringlich verlorengehen. 